Rácz Tamás Attila - Tóth Balázs

\title{
A bazai önkormányzatok pénzügyi zavarai az adósságkonszolidáció és az önkormányzati rendszer reorganizációjának tükrében
}

Összefoglaló: Az önkormányzati alrendszer adósságkonszolidációja, valamint az önkormányzatok feladatköreinek és finanszírozásának átalakitása az egyik legjelentősebb hazai közpénzügyi eseménynek tekinthető. A tanulmány keretein belül egy 230 hazai önkormányzatot magába foglaló mintán, logisztikus regresszió segítségével vizsgáljuk azt, hogy a 2005 és 2008 közötti pénzügyi adatok alapján kirajzolódnak-e valamilyen különbségek az adósságkonszolidációban részesülő, valamint az abból (korábbi adósság híján) kimaradó önkormányzatok között. Emellett a kutatás tárgya annak elemzése is, hogy az önkormányzati rendszer reorganizációja változtatott-e ezeken a különbségeken. Eredményeink alapján arra a következtetésre juthattunk, hogy a válságot megelőző időszakban a saját bevételek terén, illetve ennek köszönhetően a teljes múködési egyenlegben is jelentős különbség volt tapasztalható az adósságkonszolidációban részt vevő és abból kimaradó önkormányzatok között. A reorganizáció során kialakuló szabályozás csökkentette az önkormányzatok közötti különbséget, valamint a minta egészére vonatkozóan a pénzügyi paraméterek pozitív irányba való elmozdulása volt megfigyelhető.

Kulcsszavak: pénzügyi zavarok, önkormányzati pénzügyek, logisztikus regresszió

JEL-KóDOK: H72, H74

DOI: https://doi.org/10.35551/PSZ_2021_1_5

A rendszerváltozást követő demokratikus átalakulás az önkormányzati rendszerben is jelentős változásokat okozott. A nagymértékű decentralizáció vertikális egyensúlytalansággal járt együtt, ami az önkormányzatok eladósodásához vezetett. Ezt a folyamatot felerősítette a központi kormányzat 2005-től megfigyel-

Levelezési e-cim: racz.tamas@eco.u-szeged.hu tothbalazs@eco.u-szeged.hu hető szigorítása is (Bethlendi, Lentner, 2019). Így a 2007-2008-as válság a hazai önkormányzati szektort is sérülékeny állapotban érte el, az adósságállomány (és ezen belül a devizaadósság) növekedése dinamikussá vált, az önkormányzati szektor működése is veszélybe került. Ennek egyik legmeghatározóbb jele, hogy az önkormányzatok lejárt szállítói tartozásai összesen 69 százalékkal nőttek 2007 és 2010 között (Halmosi, 2013). Az önkormányzati al- 
rendszer rendszerváltozás óta fokozatosan kialakuló problémái az államháztartás egészét veszélyeztették, így a központi beavatkozás elkerülhetetlenné vált (Lentner, 2014) éppúgy, mint a szektor teljes reorganizációja (Báger, 2010). A tanulmány célja annak vizsgálata, hogy az adósságkonszolidáció előtt kirajzolódtak-e szignifikáns különbségek az adósságkonszolidációban részt vevő, valamint az abból kimaradó $^{1}$ önkormányzatok között. Továbbá a kutatás célkitűzése: megvizsgálni, hogy miként alakította át az önkormányzati rendszer feladatainak és finanszírozásának újjászervezése a helyi önkormányzatok pénzügyi jellemzőit, valamint az önkormányzatok között korábban kialakuló különbségeket. A dolgozat következő szerkezeti egységében a pénzügyi zavarokhoz füződő elméleti hátteret, valamint a hazai önkormányzati rendszer tapasztalatait vesszük szemügyre. Ezt követően bemutatjuk a kutatás módszertanát, majd a következő fejezetben pedig a kutatás eredményeit prezentáljuk. Végül, a dolgozat a következtetéseink összegzésével zárul.

\section{ELMÉLETI HÁTTÉR}

Ebben a szerkezeti egységben áttekintjük a pénzügyi zavarok értelmezési lehetőségeit, illetve azok kialakulásának okait. Emellett a hazai önkormányzati alrendszer korábbi problémáit a finanszírozás és feladatkörök újradefiniálását, valamint az adósságkonszolidációt mutatjuk be.

\section{Mit tekinthetünk pénzügyi zavarnak, és miért alakulnak ki?}

A vállalatok működésére vonatkozó modellek helyett speciális, az önkormányzatok működési jellegéhez jobban illeszkedő modelleket kell alkalmazni. Ennek oka, hogy a legtöbb ország- ban a csődeljárás a központi kormányzat részéről csak a legvégső megoldásnak tekinthető, a szabályozások ösztönzik az ilyen helyzetek elkerülését. A helyi önkormányzatok nem deklarálhatnak csődöt automatikusan, ha nem képesek valamelyik kötelezettségüket teljesíteni (Halmosi, 2018). Az önkormányzatok feladatainak folyamatos ellátásának kiemelt jelentősége van, így a magánszféra gazdálkodó szervezeteinél alkalmazott csődszabályozást nem lehet átültetni (Gyirán, 2014). Az önkormányzatok két osztályba sorolása (csődös és nem csődös) nem teljesen megfelelő, ugyanis figyelembe kell venni az úgynevezett látens csődeseteket is, amikor, hagyományos értelemben fizetésképtelennek tekinthetjük az önkormányzatokat (Jones, Walker, 2007; Halmosi, 2018).

Tehát, pénzügyi zavarok alatt nem csak olyan szituációkat kell érteni, amikor az adott szervezet nem tudja a pénzügyi kötelezettségeit teljesíteni, hanem ide sorolandók olyan helyzetek, amikor az önkormányzat nem képes a köz által elvárt szolgáltatásokat megfelelő minőségben nyújtani. Kloha, Weissert és Kleine (2005) tanulmányukban akkor tekintettek valamit fiskális zavarnak, ha egy önkormányzat több egymást követő évben sem érte el a működésével, adósságával kapcsolatos célokat, nem teljesítette a közösségi elvárásokat. A közszolgáltatások szintjének visszavágása több kutatásban is megjelent (Trussel, Patrick 2013; Jones, Walker, 2007). A közszolgáltatások vizsgálata is meglehetősen indokoltnak tünik ugyanis, ha feltételezzük, hogy egy önkormányzat el akarja kerülni a késedelmes fizetést vagy a nemfizetést, akkor könnyen elképzelhető, hogy egyes feladataitól von el forrásokat. Így a pénzügyi problémák indirekten, de kimutathatók már korábban is. A közszolgáltatások mérésével kapcsolatban viszont több hátrányt is ki lehet emelni. Problémás lehet a változók operacionalizálása, illetve a szolgáltatásokhoz füződő adatok elérhetősége. Másik 
akadálynak tekinthető az, hogy a közszolgáltatások iránti kereslet változik az idők során és nehéz felmérni, hogy egy adott közszolgáltatás szintje, vagy az általa elért emberek száma a keresleti oldal változásai miatt vagy a kínálati oldal helyzete miatt módosult-e.

Miért alakulnak ki pénzügyi zavarok? Trussel és Patrick (2013) az önkormányzatok által potenciálisan elérhető források és az ellátandó feladatok költsége közötti egyensúlytalanságot tekintette a problémás helyzetek forrásának, míg Skidmore és Scorsone (2011) külső (például piaci események) és belső (például gyenge pénzügyi menedzsment) tényezőket különböztetett meg. Carmelli és Cohen (2001) a fiskális problémák okának a szervezetek forráshiányát, illetve azok vezetőinek képességeit tartották, amelyek miatt a szervezet nem képes megfelelő szolgáltatások nyújtására, és alkalmazkodni a változó környezethez.

\section{Pénzügyi zavarok hazai önkormányzatoknál}

Hazánkban az önkormányzatok eladósodását központi szabályok hivatottak megakadályozni (Gál, 2011). Ilyen korlátot az önkormányzati működést szabályozó törvény 1995. évi működésekor emelték be (88.\$), amely kiköti, hogy az önkormányzatok éves adósságból eredő kötelezettségvállalása nem haladhatja meg a bevétel rövid lejáratú kötelezettségekkel csökkentett értékének 70 százalékát. Az önkormányzatok adósságrendezési eljárásáról szóló 1996. évi XXV. törvény is a túlzott eladósodást és az adósság rendezése alatt ellátandó kötelező feladatait szabja meg, valamint szabályozzák azt is, hogyan kell az önkormányzat gazdálkodásának reformálását követően a helyi közszolgáltatások folytonosságát biztosítani. A törvény kiemeli azt is, hogy a központi költségvetés nem áll kezességével az önkormányzatok mögött (Gál, 2011).
A helyi önkormányzatok mozgástere folyamatosan szűkült a rendszerváltozást követő húsz évben, a helyi közszolgáltatások biztosítása egyre nagyobb erőfeszítést igényelt. A szakpolitikai feladatok egyre nagyobb részét delegálták helyi szintre, míg a hozzájuk biztosított források értéke reálértéken csökkent. A normatív támogatások a folyó költségek egy részét fedezték, az eszközpótlásra nem jelentett forrást, holott a pótlandó eszközökkel hozzájuk kiszervezett feladatokat is elláttak az önkormányzatok. Jelentős probléma volt az önkormányzatok helyi iparűzési adó függősége is, ami túlságosan konjunktúraérzékennyé tette az önkormányzatok többségét. A fenntarthatatlan gazdálkodás irányába hatott a forrásszabályozás áttekinthetetlensége, valamint a központilag kiírt pályázatok, amelyek figyelmen kívül hagyták a helyi igényeket (Schlett, 2017). A feladat- és hatáskör-telepítés során elmaradt a differenciálás a különböző szintű és méretű települések között (Vígvári, 2009). Az ezredfordulóra így már jelentős működési hiány alakult ki. Gyakori jelenséggé vált, hogy az önkormányzatok a fejlesztési célú forrásaikat is működési kiadások fedezésére fordították (Lentner, 2014). Emellett az EU-s pályázatok is túlfütötték a beruházásokat, melyeknek célja gyakran nem a kötelező feladatellátás feltételeinek fejlesztése, eszközhatékonyságának növelés volt (Domokos, 2012). Az EU-csatlakozást követően elérhetővé vált fejlesztési lehetőségek növelték a beruházási kedvet, viszont ezekhez jellemzően hiányzott az önerő, amelyet hitelekkel, illetve devizakötvényekkel pótoltak. Ráadásul ezek nem termelő beruházásokhoz kapcsolódtak, így közvetlen hitelfedezettel nem is lehetett számolni, és ezek a projektek sok esetben a müködési kiadások növekedésével jártak (Lentner, Hegedűs, 2019). A forrásbevonások terén hiányzott az intézményes kontroll, illetve a lízing- és a PPP-konstrukciók által „bújtatott hitelfelvételek” is elterjedtek. Ezek fokozták az önkormányzatok pénz- 
ügyi kockázatainak átláthatatlanságát (Vígvári, 2010). Mindemellett a belső ellenőrzéssel kapcsolatos szabályozás sem bírt megfelelő környezetet biztosítani (Sepsey, 2011). 2011-re nyilvánvalóvá vált, hogy az 1996. évi XXV. törvény addigi formájában nem volt képes betölteni eredeti rendeltetését.

2010 előtt az önkormányzati hitelek és kötvények állománya folyamatosan emelkedett, valamint az önkormányzati szektor hitel/betét pozíciója is szinte folyamatosan romlott (Gál, 2011). Az önkormányzatok folyó költségvetési egyenlege folyamatosan romlott, a működőképesség megőrzését szolgáló kiegészítő támogatások nemhogy a hosszú távú egyensúlyt nem biztosították, hanem rövid távon sem bizonyultak elégségesnek. További problémának tekinthető az is, hogy a tartós müködési és felhalmozási hiányt gyakran likviditási hitelekkel finanszírozták (Domokos, 2012).

Az önkormányzatokhoz delegált feladatok jellemzően alulfinanszírozottak voltak (Hegedűs, Novoszáth, 2018). A lokális alrendszer problémáit az Állami Számvevőszék ellenőrzései is igazolták, ahol egyszerre jelent meg a müködési és felhalmozási forráshiány, az önkormányzatok nem rendelkeztek a kötelezettségek teljesítéséhez szükséges eszközökkel (Lentner, 2014). A rendszert jellemző ellentmondásokat a mindenkori kormányzat a fiskális politikával tudta kezelni, ami egyre rombolóan hatott (Vígvári, 2010).

Figyelembe véve a hazai tapasztalatokat, itt is hasonló okokat állapíthatunk meg: érvényesül a Trussel és Patrick (2013) által felvázolt alulfinanszírozási indok. Illetve Skidmore és Scorsone (2011) kategorizálása szerint meg tudunk különböztetni külső (nem megfelelő központi finanszírozás, konjunktúraérzékeny bevételek és kedvezőtlen piaci környezet, nem megfelelő pályázati rendszer) és belső okokat (pazarló gazdálkodás, meggondolatlan beruházások). A Kloha, Weissert és Kleine (2005) által bemutatott okok közül megfigyelhettük az adóalapok csökkenését, az önkormányzati kiadások fokozódását és az elhibázott gazdálkodási döntéseken keresztül az önkormányzati városvezetéseket is meg lehet említeni a problémák forrásaként. Mindemellett az önkormányzati rendszert jellemző, belső kontrollelégtelenségeket (Sepsey, 2011; Benedek, Szenténé Tubak, Béres, 2014) pedig a gyenge menedzsment megnyilvánulásának tekinthetjük. Bár, ahogy Lentner (2014) is kiemeli az önkormányzati alrendszer eladósodása elsődleges okának az állami szabályozás és ellenőrzés hiánya, a gyenge és decentralizációra kényszerülő fiskális politika, valamint az önkormányzatoknak nagy szabadságot adó, de a források terén szigorító neoliberális alapfilozófia tekinthető, amely felelőtlen költségvetési gyakorlattal egészült ki.

Az önkormányzati rendszer reformja és a 2011-2014-es adósságkonszolidáció

Az önkormányzati alrendszer reorganizációja iránti szükség vitathatatlanná vált. A helyzet újbóli kialakulásának elkerülését megcélozva több intézkedés is született. A kontroll erősítése mellett (amely az újra eladósodás megakadályozásának egyik legfőbb eszközévé vált) egyéb változtatásokat is alkalmaztak a szabályozásban. Ilyen például a működési költségek hitelből való finanszírozásának tilalma, ami 2013-tól van érvényben. Szintén jelentős átalakulás következett be az önkormányzatok által ellátandó feladatok körében. A fekvőbeteg-ellátás 2012től, az iskolák üzemeltetése 2013-től került állami feladatkörbe. Emellett, a járási hivatalok létrehozásával több államigazgatási feladat is kikerült az önkormányzatok kötelezettségei közül (Hegedűs, Novoszáth, 2018). Az óvodák és gyermekétkeztetés működtetése és fenntartása helyi feladat maradt, viszont a dolgozók bérének egy része központi finanszírozású lett. Helyi szinten maradt a méltányossági segélyezés, 
az alapszolgáltatások és ellátások biztosítása, nappali ellátás, továbbá a hajléktalanok átmeneti gondozása (Lentner, 2019).

$\mathrm{Az}$ adósságkonszolidációra 2011 és 2014 között több ütemben került sor (lásd 1. táblázat).

2010 után az ÁSZ feladata is növekedett a megfelelő önkormányzati gazdálkodás biztosításában. Az ÁSZ intézkedései támogatták a jó gyakorlatok elterjedését és a megfelelő belső ellenőrzést támogató jogszabályi környezet kialakítását (Sepsey, 2011). A belső kontrollrendszerek fejlesztése szabályszerü, eredményes és hatékony gazdálkodás ösztönzését segíti elő (Benedek, Szenténé Tubak, Béres 2014). Mindehhez az ÁSZ-nak az integritási kultúra terjesztésében betöltött szerepe is pozitívan járult hozzá (Domokos és szerzőtársai 2015). Az ÁSZ eszközei segítik a működési hiány kordában tartását, a befektetések vizsgálatát, az integritási kockázatok csökkentését. Emellett, a Stabilitási törvény és a Magyarország helyi önkormányzatairól szóló törvényben lefektetett szabályozások engedélykötelessé tették az önkormányzatok hitelfelvételét. A szabályozó meghagyta az EU-s finanszírozású projektek önrészének hitelből való előteremtésének lehetőségét, viszont csak jelentős korlátozások mellett (Hegedűs, Lentner, Molnár, 2019). 2013tól az önkormányzatok nem tervezhetnek költségvetésükben működési veszteséget, illetve a szabályozás által említett feltételek szerint fejlesztési célú források mellett csak likviditási hiteleket vonhattak be (Lentner, 2019).

A gazdálkodási szabadság korlátozása mellett a finanszírozás alapelve is megváltozott, ugyanis a helyi önkormányzatok finanszírozási rendszere már a feladatfinanszírozás keretein belül történik. Ennek keretein belül a helyi önkormányzat által kötelezően ellátandó feladatok müködési kiadásait az Országgyűlés feladatalapú finanszírozással támogatja, az ellátandó feladatokhoz a jogszabályokban meghatározott közszolgáltatási szintnek megfelelő támogatást biztosít. (Lentner, 2019). Az önkormányzatok a feladatok és finanszírozásuk összehangolása, valamint az adósságkonszolidáció lefolyása után tiszta lappal indulhattak (Hegedűs, Novoszáth, 2018). Az önkormányzati rendszer kiadásai az államháztartás kiadásainak 11-12 százalékára esett vissza a korábbi 20 százalékról (Lentner, 2019).

A bemutatott változások alapján a következő hipotéziseket fogalmazhatjuk meg:

- H1: az adósságkonszolidációt megelőzően a pénzügyi zavarokkal küzdő és a jól müködő önkormányzatok pénzügyi paraméterei szignifikánsan eltértek egymástól.

- H2: az adósságkonszolidációt és újraszabályozást követően a két csoport pénzügyi

1. táblázat

\section{AZ ADÓSSÁGKONSZOLIDÁCIÓ LÉPÉSEI}

\begin{tabular}{|l|l|c|c|}
\hline Év & \multicolumn{1}{|c|}{ Érintett önkormányzatok } & $\begin{array}{c}\text { Önkormányzatok } \\
\text { száma }\end{array}$ & $\begin{array}{c}\text { Konszolidált összeg, } \\
\text { milliárd forint }\end{array}$ \\
\hline 2011 & Megyei önkormányzatok és fővárosi önkormányzat & 20 & 198 \\
\hline 2012 & 5000 fő alatti önkormányzatok I. ütem & 1700 & 74 \\
\hline 2013 & 5000 fő alatti önkormányzatok II. ütem & 14 & 10 \\
\hline 2013 & 5000 fő feletti önkormányzatok I. ütem & 305 & 685 \\
\hline 2014 & 5000 fô feletti önkormányzatok II. ütem & 305 & 420 \\
\hline
\end{tabular}

Forrás: Hegedűs, Novoszáth (2018) alapján saját szerkesztés 
mutatói közötti különbségek összességében mérséklődtek.

-H3: az önkormányzatok korábban problémás pénzügyi paraméterei javultak az adósságkonszolidációt követően.

\section{ADATOK ÉS MÓDSZERTAN}

Mintavétel során az önkormányzatok adósságkonszolidációját, a rendkívüli támogatások mértékét és a települések lakónépességet vettük figyelembe. Az elemzésbe bevont változók kiválasztásakor tekintettel kellett lennünk arra, hogy csak kemény változók álltak rendelkezésre (pénzügyi adatok, demográfiai adatok). Mivel a logisztikus regressziós modell érzékeny a multikollinearitásra, ennek elkerülése érdekében két szinten (pénzügyi egyenlegek, egyedi pénzügyi mutatók) is vizsgálódtunk.

\section{A jól múködő és a pénzügyi zavarokkal rendelkező önkormányzatok kiválasztása}

A jól működő intézmények csoportjába az adósságkonszolidációban nem részesült önkormányzatokat soroltuk. Ehhez egy 2015 októberében született miniszteri döntést használtunk fel, amelyben az állam az adósságkonszolidációban (főleg tartozás híján) nem részesülő, 115 darab önkormányzatot fejlesztési támogatásban részesített. ${ }^{2}$ A másik, pénzügyi zavarokkal küzdő csoport létrehozásához az önkormányzatok rendkívüli támogatásait vettük figyelembe. ${ }^{3}$ Azt a 115 önkormányzatot soroltuk pénzügyi zavarokkal küzdő önkormányzatokat közé, melyek egyrészt hasonló lakónépességgel rendelkeznek, mint az adósságkonszolidációban nem részesült önkormányzatok, másrészt a legnagyobb egy före jutó rendkívüli támogatásokban részesültek 2014-ben. A lakónépességre - mint szürőre - azért volt szükség, mert a jól működő önkormányzatok lakossága viszonylag szük intervallumba esik az összes településhez képest (lásd 1. ábra).

Erre Bethlendi, Lentner és Nagy (2020) is felhívták a figyelmet tanulmányukban, amelyben klaszteranalízisek segítségével öt csoportba sorolták a magyar településeket. Az elemzések során az önkormányzatok pénzügyi paraméterei mellett a települések egyéb gazdasági mutatóit is figyelembe vették és megállapították, hogy a létrejött klaszterek közül az egyik domináns klaszterbe tartoznak az adósságkonszolidációban nem részesült önkormányzatok. Ez a klaszter pedig jobbára kisebb méretű településekből állt, amelyek a vizsgált időszakban előnyös gazdasági, illetve kedvező eszköz- és likviditási mutatókkal rendelkeztek. Ezért a jól működő önkormányzatokra jellemző - 1800 és 10000 fö közé eső - lakónépességgel rendelkező települések közül választottuk ki a pénzügyi zavarokkal küzdő önkormányzatoknak minősített csoportot is. Ebben az esetben is 115 önkormányzatot választottunk, mivel a logisztikus regressziós eljárás interpretálhatóságának szempontjából a két részminta azonos arányú eloszlása az optimális. A 2014-es évre pedig az adósságkonszolidációk lezárulása, illetve az adatok elérhetősége miatt esett a választásunk.

\section{Változók}

Modellünk magyarázóváltozói között igyekeztünk feltüntetni azokat a tényezőket, amelyek a bemutatott szakirodalom szerint indokolhatják a zavarok kialakulását.

Az elemzéshez a Központi Statisztikai Hivatal (KSH) Tájékoztatási adatbázisának éves településstatisztikai adatait használtuk fel. A fontosabb pénzügyi egyenlegeket, az önkormányzatok pénzügyi pozícióját az úgynevezett Credit Local France (CLF-) módszer segítségével határoztuk meg (2. táblázat). 


\section{MAGYARORSZÁGI TELEPÜLÉSEK LAKOSSÁGA, LAKOSSÁGSZÁM ALAPJÁN CSÖKKENÕ SORRENDBEN}

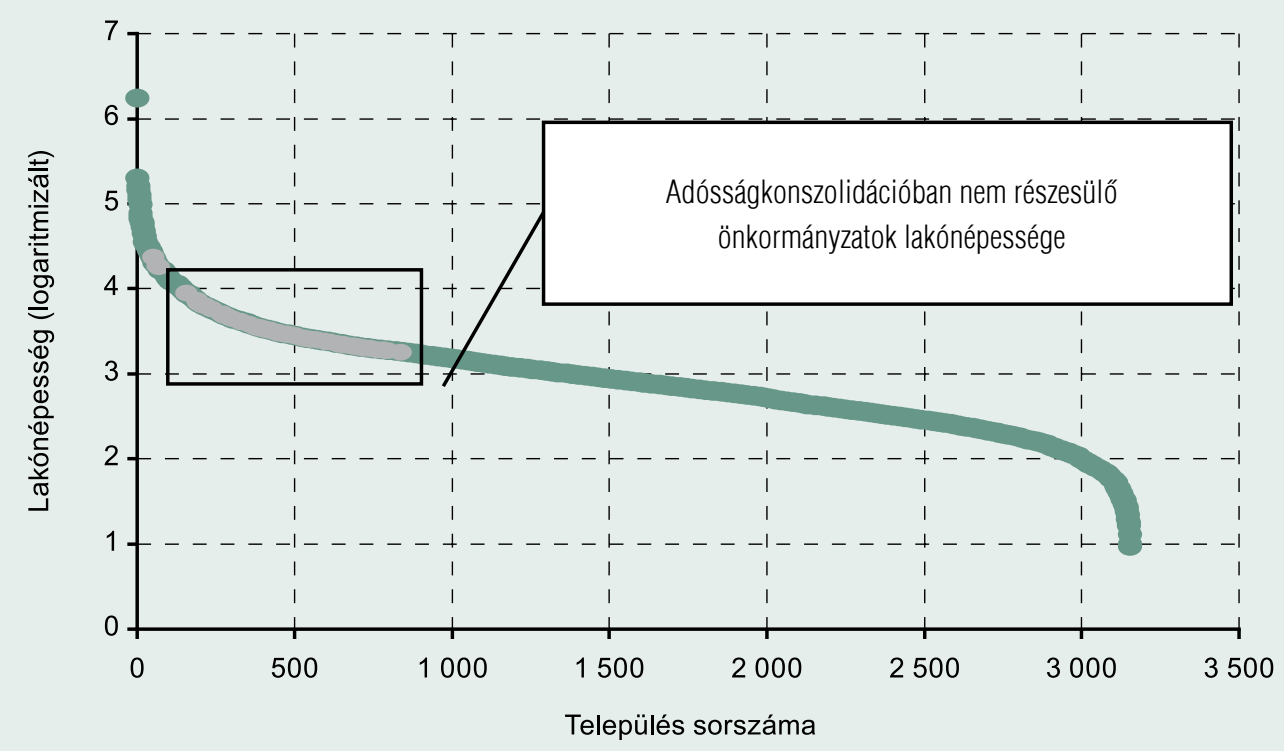

Forrás: saját szerkesztés

2. táblázat

\section{A CREDIT LOCAL FRANCE (CLF-) MÓDSZER FELÉPÍTÉSE}

1. Múködési bevételek

2. Múködési kiadások

3. Múködési jövedelem (1.-2.)

4. Felhalmozási bevételek

5. Felhalmozási kiadások

6. Felhalmozási költségvetés egyenlege (4.-5.)

\section{Tárgyévi bevételek}

8. Tárgyévi kiadások

9. GFS-pozíció (7.-8.)

10. Finanszírozási múveletek egyenlege

11. Tárgyévi pozíció $(9 .+10$.)

12. Hiteltörlesztés, értékpapír-beváltás

13. Nettó múködési jövedelem (3.-12.)

Forrás: Lentner (2019)

A módszer a cash flow kimutatások logikáját követi, szétválasztva a folyó- és a tőkeköltségvetést. A működési jövedelem pozitív értékéből arra lehet következtetni, hogy az önkormányzat a forrásokat megfelelően, hatékonyan használja fel (Lentner, 2019). A felhalmozási egyenleg a különböző felhalmozási jellegü bevételek (beruházási céltámogatások, ingatlanértékesítés) és kiadások (beruházások, beruházásokra átadott pénzeszközök) különbsége (Vasvári, 2013). Cash flow szempontjából az egyenleg pozitív értéke az előnyös, de a negatív 
érték sem jelent feltétlenül problémát, ha az megfelelően finanszírozott, jövőben megtérülő beruházás miatt alakul ki. A tárgyévi egyenleg (GFS-pozíció) a tárgyévi bevételek és kiadások különbsége, amely a költségvetés elsődleges, finanszírozási jellegű tételek nélküli pozícióját mutatja. A finanszírozási műveletek egyenlege alatt a hitelfelvételeket és törlesztéseket, illetve a költségvetési maradványt, mint belső finanszírozási forrás felhasználását értjük. A tárgyévi pozíció pedig megmutatja, hogy pénzbeáramlás vagy pénzkiáramlás történt az adott évben, tehát egyfajta eredményességi mutatóként szolgál. Jelentős összegű beruházások esetében ugyan nem probléma a mutató negatív értéke, de ha tartósan, éveken keresztül negatív értéket mutat, az pénzügyileg nem fenntartható állapotot jelent (Lentner, 2019).

A változók esetében két 4 éves periódus átlagos értékei alapján vizsgálódtunk. A válságot megelőző 2005 és 2008 közötti, illetve az adósságkonszolidációt követő 2015 és 2018 közötti periódusok alapján. Az adósságkonszolidációt megelőző időszakot azért időzítettük korábbra, mert egyes önkormányzatoknál már 2009-től kezdve a pénzügyi zavarok jelei mutatkoztak az egyes mutatókban, jelen tanulmány célja pedig nem az önkormányza- tok válsággal való küzdelmének a bemutatása, hanem az önkormányzati gazdálkodásban általánosan végbemenő változások feltérképezése az adósságkonszolidáció és a reorganizáció tükrében. A második időszak kiválasztásának az oka, hogy a KSH Tájékoztatási adatbázisában hiányosak a 2012-tól 2014-ig terjedő éves adatok.

Ezt követően a részminták következtetések levonására való alkalmasságát ellenőriztük. A kapott eredményeinket nagymértékben torzíthatja, ha a két önkormányzati csoportunk a pénzügyi paramétereket leszámítva is jelentős mértékben eltér egymástól. Ennek érdekében a lakosságszám mellett a rendelkezésre álló források, illetve a felhalmozási és tőkejellegü kiadások szemszögéből is összehasonlítottuk a csoportokat. Előbbit azért tartottuk fontosnak ellenőrizni, hogy költségvetési szempontból is hasonló méretű önkormányzatok kerültek mind a két csoportba. A felhalmozási kiadásokban tapasztalható különbségek torzító hatásaira pedig Bethlendi, Lentner és Nagy (2020) világítottak rá. Tanulmányuk szerint a magyar települések pénzügyi és gazdasági jellemvonásai jelentős mértékben eltérnek azokban az időszakokban, amikor jelentősebb beruházásokat hajtanak végre. A 3. táblázatban jól

3. táblázat

\section{A KÉT CSOPORT HASONLÓSÁGÁT JELLEMZŌ MUTATÓSZÁMOK STATISZTIKÁI (2005-2008)}

\begin{tabular}{|c|c|c|c|c|c|}
\hline Változó & Gsoport & Átlag & Szórás & Medián & $\begin{array}{c}\text { Mann-Whitney- } \\
\text { próba }\end{array}$ \\
\hline \multirow[t]{2}{*}{ Lakosság (fő) } & Jól múködő & 3630,1 & 3055,1 & 2855,5 & \multirow{2}{*}{0,132} \\
\hline & Pénzügyi zavar & 3662,3 & 1673,9 & 3010,0 & \\
\hline \multirow{2}{*}{$\begin{array}{l}\text { Rendelkezésre álló források } \\
\text { (ezer Ft/fő) }\end{array}$} & Jól múködő & 203,1 & 112,5 & 173,3 & \multirow{2}{*}{0,002} \\
\hline & Pénzügyi zavar & 239,7 & 125,9 & 215,6 & \\
\hline \multirow{2}{*}{$\begin{array}{l}\text { Felhalmozási és tôkejellegú } \\
\text { kiadások (ezer Ft/fő) }\end{array}$} & Jól működő & 31,8 & 56,1 & 20,1 & \multirow{2}{*}{0,388} \\
\hline & Pénzügyi zavar & 37,0 & 71,1 & 21,7 & \\
\hline
\end{tabular}

Forrás: saját szerkesztés 
látható, hogy nemcsak a méret, de a beruházási aktivitás tekintetében is hasonlónak tekinthető a két részminta. Ezt az átlagok mellett a lakosságszám és a felhalmozási kiadások esetében a két minta azonos eloszlásának tesztelésére alkalmas Mann-Whitney-próbák is alátámasztják (Nachar, 2008). Ezzel szemben a rendelkezésre álló források esetében eltérő ugyan a minták eloszlása és szignifikánsan magasabb a pénzügyi zavarokkal rendelkező csoport átlagos értéke, úgy gondoljuk, ez a 18 százalékos különbség az elemzésekből levont következtetéseinket nem rombolja jelentősen. A nagyobb mértékű szórások pedig azzal magyarázhatók, hogy néhány kiugró érték is a mintába került.

\section{Módszertan}

A jól működő és a pénzügyi zavarokkal küzdő önkormányzatok egymástól való elkülönülésének vizsgálatához logisztikus regressziókat alkalmaztunk. A választásunk több okból esett erre az eljárásra. Egyrészt, a két időszakban bekövetkezett változásokat és a két csoport egymáshoz való relatív helyzetét (közeledését vagy éppen eltávolodását) akartuk megragadni egzakt mutatószámokkal. Ezt a logisztikus regressziós eljárások során kapott pszeudó R-négyzetek, a becsült valószínűségi változókból létrehozott klasszifikációs táblák és az ehhez kapcsolódó ROC-görbék segítségével egyszerüen és közérthetően lehet szemléltetni. Másrészt, a logisztikus regresszió felépítése és az eredményekből levonható következtetések egyszerűbben megragadhatók, mint például egy neurális háló esetében. Továbbá, az eljárás ugyan érzékeny a kiugró értékekre és a multikollinearitásra, nem követeli meg a változók normális eloszlását és kevésbé torzítja az eredményeit a változók között fennálló heteroszkedaszticitás, ezért nem feltétlenül szükséges a változókon összetettebb matematikai transzformációkat végrehajtani.
A bináris logisztikus regresszió általános egyenlete az alábbi formulával írható fel:

$$
p\left(x_{i}\right)=P\left(y_{i}=1 \mid x_{i}\right)=\frac{\exp \left(\beta_{0}+\sum_{j=1}^{p} \beta_{i} x_{i j}\right)}{1+\exp \left(\beta_{0}+\sum_{j=1}^{p} \beta_{j} x_{i j}\right)}
$$

Melyben:

$p\left(x_{i}\right)=$ pénzügyi zavar fennállásának valószínüsége önkormányzatra nézve ${ }^{4}$

$\beta_{0}=$ konstans értéke

$\beta_{j}=\mathrm{a} j$ független változó regressziós paraméterének becslése

$x_{i j}=i$ önkormányzat $j$ magyarázóváltozójának az értéke

Az egyes magyarázóváltozókhoz tartozó regressziós paraméterek természetes alapra történő emelése a változókban bekövetkező egységnyi változás esélyhányadosra (odds) gyakorolt hatásait mutatják meg (Hardle, Simar, 2015). $\mathrm{Az}$ eredmények során ezeket az értékeket $\operatorname{Exp}(B)$ jelöléssel közöljük.

Az önkormányzatok méretbeli különbségét úgy kezeltük, hogy a mutatókat minden esetben osztottuk a lakónépesség számával. Emiatt a változóink mértékegysége minden esetben ezer forint per fóben értelmezendők. A kiugró értékek mérséklésének érdekében a változók természetes alapú logaritmusait vettük. ${ }^{5}$ A multikollinearitást pedig úgy kezeltük, hogy az egymással szorosan összefüggő, egymás lineáris kombinációjából előállítható változókat nem szerepeltettünk ugyanazon egyenletekben. Így a 2005 és 2008 közötti időszakra vonatkozóan a CLF-modellben szereplő egyenlegeket vizsgáltuk, a nettó működési jövedelem kivételével (amely a működési egyenleg és a finanszírozási egyenlegben is megjelenő hiteltörlesztések különbsége). Ezzel ellentétben a 2014-ben bekövetkező számviteli és módszertani változások miatt a Tájékoztatási Adatbázis adatai alapján nem lehetett egyértelműen elkülöníteni a finanszírozási bevételeket, ezért erre az időszakra vonatkozóan ezt nem vontuk be az elemzésbe. A vizsgálatba vont változókat és a szakirodalom alapján elö- 
zetesen elvárt hatásaikat a pénzügyi zavarokkal rendelkező csoportba sorolás valószínűségére a 4. táblázat mutatja.

A logisztikus regressziók során minden esetben a varianciainflációs tényezők (VIF-értékek) segítségével ellenőriztük az esetlegesen fennálló multikollinearitást. Az elemzéseket SPSSszoftverben végeztük, a hatások vizsgálatához pedig Wald-teszteket használtunk.

\section{EREDMÉNYEK}

Az eredmények alapján két dolgot állapíthatunk meg. Egyrészt, hogy az adósságkonszolidációt megelőző időszakban a működési és a finanszírozási egyenlegük alapján valóban jelentős mértékben eltértek egymástól az adósságkonszolidációban nem részesült, esetünkben jól működő és az adósságkonszolidációban részt vevő, pénzügyi zavarokkal rendelkező önkormányzatok. Másrészt, hogy az adósságkonszolidációt követő években, habár a saját működési bevételeik és kiadásaik továbbra is jelentős mértékben eltértek egymástól, az állam támogatásainak köszönhetően már nem mutatkozott jelentősebb különbség a két csoport között.

\section{A két csoport elkülönülése}

Az 5. táblázatban jól látható, hogy a 20052008-ig terjedő időszakban a két csoport elsősorban a működési és a finanszírozási egyenlegek alapján különült el egymástól. A magasabb működési egyenleg csökkentette a pénzügyi zavarok kialakulásának a valószínűségét, míg a magasabb finanszírozási egyenleg már ekkor előre jelezte a problémák kialakulását. Az elkülönülés mértéke is igen jelentős volt, amit egyrészt a magas pszeudó R-négyzet-érték és a ROC-görbe alatti terület is jelez, másrészt, hogy a logisztikus regressziós modell becslése 79,6 százalékos találati pontossággal volt képes megfelelő csoportba sorolni az önkormányzatokat, kezdeti, 50 százalékos cut-off érték mellett.

$\mathrm{Az}$ adósságkonszolidációt követő időszakban a működési jövedelem tekintetében már jelentős közeledés történt a két csoport között. Ebben az időszakban a felhalmozási egyenlegben volt szignifikáns különbség tapasztalható a két csoport

4. táblázat

\section{A VIZSGÁLATBA VONT VÁLTOZÓK ÉS A SZAKIRODALOM ALAPJÁN ELÖZETESEN ELVÁRT HATÁSAIK A PÉNZÜGYI ZAVAROKKAL RENDELKEZÖ CSOPORTBA SOROLÁS VALÓSZÍNÚSÉGÉRE}

\begin{tabular}{|c|c|c|c|}
\hline Idöszak & Változó (ezer Ft/fó) & Jelölés & Várható elöjel \\
\hline \multirow{2}{*}{$2005-2008$} & Múködési egyenleg & MJ & Negatív \\
& Felhalmozási egyenleg & FE & - \\
\hline & Finanszírozási egyenleg & FI & Pozitív \\
& Tárgyévi egyenleg & GFS & Negatív \\
\hline \multirow{2}{*}{$2015-2018$} & Múködési egyenleg & MJ & Negatív \\
& Felhalmozási egyenleg & FE & - \\
\hline
\end{tabular}

Forrás: saját szerkesztés 
5. táblázat

LOGISZTIKUS REGRESSZIÓS MODELL A 2005-2008-AS IDŐSZAKBAN

\begin{tabular}{|l|r|r|r|r|r|r|}
\hline \multicolumn{1}{|c|}{ Változó } & $\mathbf{B}$ & $\mathbf{S . E .}$ & Wald & Sig. & Exp(B) & VIF \\
\hline Mú́ködési egyenleg & $\mathbf{- 0 , 9 3 8}$ & $\mathbf{0 , 1 9 8}$ & $\mathbf{2 2 , 3 9 5}$ & $\mathbf{0 , 0 0 0}$ & $\mathbf{0 , 3 9 2}$ & $\mathbf{1 , 6 3 1}$ \\
\hline Felhalmozási egyenleg & $-0,250$ & 0,203 & 1,512 & 0,219 & 0,779 & 1,339 \\
\hline Finanszírozási egyenleg & $\mathbf{0 , 4 5 4}$ & $\mathbf{0 , 1 4 0}$ & $\mathbf{1 0 , 4 7 7}$ & $\mathbf{0 , 0 0 1}$ & $\mathbf{1 , 5 7 5}$ & $\mathbf{1 , 4 1 3}$ \\
\hline Tárgyévi egyenleg & $-0,159$ & 0,131 & 1,474 & 0,225 & 0,853 & 1,336 \\
\hline Konstans & $-3,447$ & 0,813 & 17,963 & 0,000 & 0,032 & \\
\hline
\end{tabular}

Találati arány: 79,6\%; Nagelkerke pszeudó R-négyzet: 0,429; ROC-görbe alatti terület: 0,849

Forrás: saját szerkesztés

\begin{tabular}{|c|c|c|c|c|}
\hline \multirow{2}{*}{\multicolumn{2}{|c|}{ Klassziffkációs tábla }} & \multicolumn{2}{|c|}{ Modell alapján becsitlt } & \multirow{2}{*}{$\begin{array}{c}\text { Helyes besorolási } \\
\text { arány (\%) }\end{array}$} \\
\hline & & Jól mt́lködó & Pénzitgyi zavar & \\
\hline \multirow[t]{2}{*}{ Tényleges } & Jól múködő & 89 & 26 & 77,39 \\
\hline & Pénzügyi zavar & 21 & 94 & 81,74 \\
\hline Összesen & & & & 79,56 \\
\hline
\end{tabular}

Forrás: saját szerkesztés

között. Az adósságkonszolidációban nem részesült települések egyenlege általában alacsonyabb volt, mint a pénzügyi zavarokkal rendelkező önkormányzatok esetében (6. táblázat). A felhalmozási egyenleg különbsége azonban közel sem volt olyan mértékü, hogy azzal hatékonyan el lehessen egymástól különíteni a két csoportot. A regressziós modell becslései alapján az előző időszakkal ellentétben jóval alacsonyabb, csupán 64,8 százalékos találati aránnyal lehetett az önkormányzatokról eldönteni, hogy korábban melyik csoportba tartoztak. Ezzel konzisztensen a pszeudó R-négyzetek és a ROC-görbe alatti terület mértéke is jóval alacsonyabb a korábbi időszakhoz képest. Illetve, ahogyan azt korábban is említettük az alacsonyabb felhalmozási egyenleg önmagában alapvetően nem feltétlenül jelent problémát. Ráadásul ezek a települések jelentős állami támogatásban is részesültek 2014-ben, annak köszönhetően, hogy korábban nem volt szükség a kimentésükre.
Szakadék az önkormányzatok működési egyenlegeiben

Ha az első időszakban a működési és a finanszírozási egyenlegen belül megvizsgáljuk a legfontosabb tényezők hatásait, jól látható, hogy az adósságkonszolidációban részesült önkormányzatok esetében a müködési bevételek közül a saját folyó bevételek nagymértékben elmaradtak. Ahogy az a 2. ábrán is megfigyelhető, a saját működési bevételek egy före vetített értéke általában alacsonyabb volt a pénzügyi zavarokkal rendelkező csoportban. Ez nagyrészt a helyi adóbevételeknek köszönhető, mely általában elmaradt a jól mủködő önkormányzatokétól. Emellett, a kiadási oldalon is jelentős különbségek voltak megfigyelhetők, amelyet nagyrészt a személyi ráfordítások okoztak. Az ezekből az eltérésekből fakadó, saját működési egyenlegben kialakult különbözetet csak részben kompenzálták a műkö- 
6. táblázat

\section{LOGISZTIKUS REGRESSZIÓS MODELL A 2015-2018-AS IDŐSZAKBAN}

\begin{tabular}{|l|c|r|r|r|r|c|}
\hline \multicolumn{1}{|c|}{ Változó } & B & S.E. & Wald & Sig. & Exp(B) & VIF \\
\hline Múködési egyenleg & 0,184 & 0,115 & 2,567 & 0,109 & 1,202 & 1,515 \\
\hline Felhalmozási egyenleg & $\mathbf{0 , 3 5 0}$ & $\mathbf{0 , 0 7 3}$ & $\mathbf{2 2 , 9 0 6}$ & $\mathbf{0 , 0 0 0}$ & $\mathbf{1 , 4 2 0}$ & $\mathbf{1 , 7 2 8}$ \\
\hline Tárgyévi egyenleg & $-0,169$ & 0,107 & 2,481 & 0,115 & 0,845 & 1,928 \\
\hline Konstans & $-0,516$ & 0,350 & 2,170 & 0,141 & 0,597 & \\
\hline
\end{tabular}

Találati arány: 64,8\%; Nagelkerke pszeudó R-négyzet: 0,171; ROC-görbe alatti terület: 0,717

Forrás: saját szerkesztés

\begin{tabular}{|c|c|c|c|c|}
\hline \multirow{2}{*}{\multicolumn{2}{|c|}{ Klasszifikációs tábla }} & \multicolumn{2}{|c|}{ Modell alapjăn becsitlt } & \multirow{2}{*}{$\begin{array}{l}\text { Helyes besorolási } \\
\text { arány (\%) }\end{array}$} \\
\hline & & Jól mứködó & Pénzitgyi zavar & \\
\hline \multirow[t]{2}{*}{ Tényleges } & Jól múködő & 67 & 48 & 58,26 \\
\hline & Pénzügyi zavar & 33 & 82 & 71,30 \\
\hline Összesen & & & & 64,78 \\
\hline
\end{tabular}

Forrás: saját szerkesztés

\section{A PÉNZÜGYI ZAVAROKKAL RENDELKEZŐ ÖNKORMÁNYZATOK ÁTLAGOS KÜLÖNBÖZETEI A JÓL MÚKKÖDÖ ÖNKORMÁNYZATOKHOZ KÉPEST (2005-2008)}

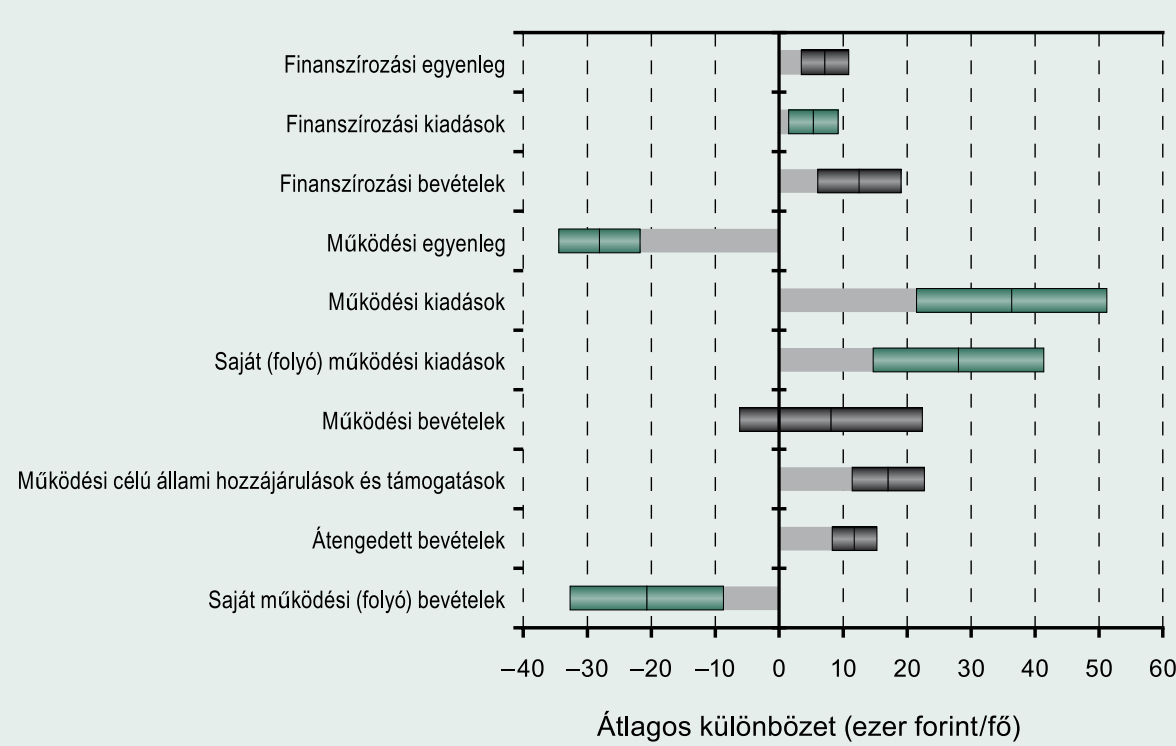

Megjegyzés: Az átlaghoz tartozó 95 százalékos konfidenciaintervallumok zöld (múködés szempontjából hátrányos különbözet), illetve fekete (múködés szempontjából előnyös különbözet) színnel szemléltetve.

Forrás: saját szerkesztés 
dési támogatások. Így számottevő szakadék alakult ki a két csoport között. Ezzel is magyarázható, hogy a később nagymértékű adósságkonszolidációra szoruló önkormányzatok általában nagyobb értékben vettek fel hiteleket, vagy vették igénybe belső maradványaikat, amelyek a finanszírozási egyenlegüket pozitív irányba növelte.

Ehhez hasonlóan, ha a második időszakban a müködési és a felhalmozási egyenleget bontjuk részelemeire, megállapíthatjuk, hogy a saját müködési bevételek átlagos különbözete nem változott jelentősebb mértékben. Ez az eltérés továbbra is a saját bevételi forrás, a helyi adóbevételek különbségével magyarázható, azonban a kiadási oldalon tapasztalható különbség megnövekedett, ami az olló szétnyílását jelzi (3. ábra). A különbözet nagy része ebben az időszakban is a sze- mélyi juttatások miatt alakult ki. Felmerülhet a kérdés, hogy a közel azonos méretü önkormányzatoknál mi indokolja ennek a jelentős különbségnek a kialakulását. Egy korábbi pilotkutatásban olyan demográfiai tényezőket is szerepeltettünk a modellben, mint a munkanélküliségi rátát vagy a munkaképes korú lakosság arányát, azonban ezek egyike sem bizonyult szignifikáns változónak. Ebből arra lehet következtetni, hogy a munkanélküliségi rátát a pénzügyi zavarokkal rendelkező önkormányzatok közfoglalkoztatásokkal tartják alacsonyabb szinten. Ezt az állításunkat alátámasztja, hogy a 2017-es és 2018-as év átlagában jóval magasabb volt a közfoglalkoztatottak átlagos aránya a korábban adósságkonszolidációban részesülő önkormányzatok körében. A jól működő önkormányzatok esetében a munkanélküliségi ráta átlagos érté-

\section{A PÉNZÜGYI ZAVAROKKAL RENDELKEZÖ ÖNKORMÁNYZATOK ÁTLAGOS KÜLÖNBÖZETEI A JÓL MÚKOÖDÓ ÖNKORMÁNYZATOKHOZ KÉPEST (2015-2018)}

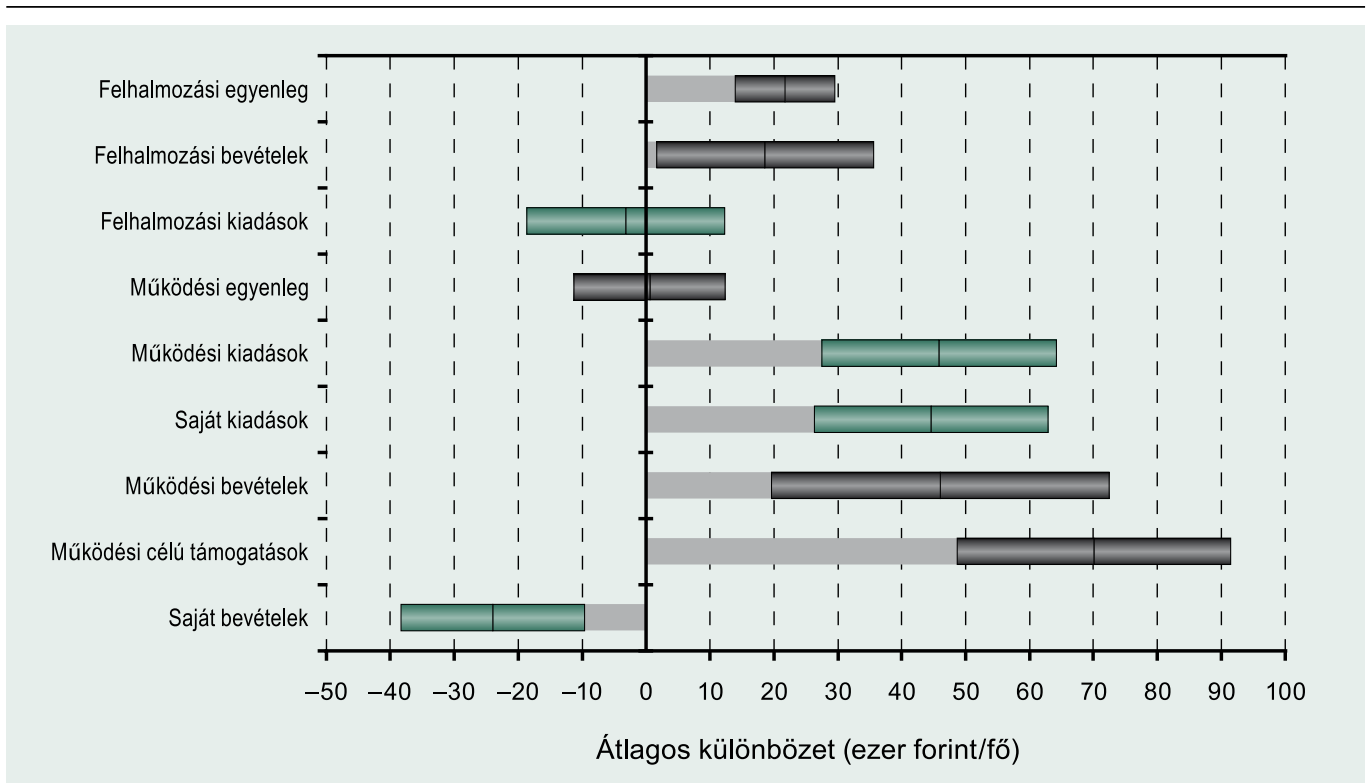

Megjegyzés: Az átlaghoz tartozó 95 százalékos konfidenciaintervallumok zöld (múködés szempontjából hátrányos különbözet), illetve fekete (múködés szempontjából előnyös különbözet) színnel szemléltetve.

Forrás: saját szerkesztés 
ke 3,30 százalék, míg a teljes lakosságra vetített közfoglalkoztatottak aránya 1,91 százalék volt. Ehhez képest a pénzügyi problémákkal rendelkező önkormányzatok munkanélküliségi rátájának átlagos értéke 1,17 százalékponttal volt magasabb, a közfoglalkoztatottak aránya pedig 2,14 százalékponttal, azaz több mint kétszer magasabb volt. ${ }^{6}$ Így közvetetten demográfiai tényezők hatásai is igazolhatók.

$\mathrm{Az}$ adósságkonszolidációt követően a növekvő működési jövedelemkülönbözetek mellett az átengedett bevételek és normatív támogatások rendszerét felváltotta a feladatalapú finanszírozás, ami már nagyobb összegben, megfelelőbb mértékben kompenzálta ezeket a különbségeket. A korábban pénzügyi zavarokkal rendelkező önkormányzatok működési bevételeinek átlagos különbözete már jóval magasabb volt ebben az időszakban, mit 10 évvel korábban. Ebből adódóan a működési egyenlegük közel egy szintre került. Emellett a felhalmozási egyenlegeik is nagymértékben növekedtek. Ez nem feltétlenül annak köszönhető, hogy az önkormányzatok jelentősebb beruházásokba kezdtek, hiszen a kiadási oldalon nem volt jelentősebb különbség tapasztalható. A bevételi oldalon figyelhető az meg, hogy a korábban adósságkonszolidációban részesült önkormányzatok jóval nagyobb mértékű felhalmozási támogatásokban is részesültek.

\section{Az állami támogatások megváltozott szerepe}

Annak érdekében, hogy az állami támogatások megváltozott szerepét szemléltessük, mind a két időszakra végeztünk egy-egy logisztikus regressziót úgy, hogy az egyenlegek során az állami támogatásokat nem vettük figyelembe. Ennek alapján a 7. táblázatban látható, hogy mind a két időszakban, hasonló hatékonysággal lehetett volna elkülöníteni az önkormányzatok két csoportját. Azonban amíg az első időszakban az állami támogatások nem voltak képesek a jól működő és a problémás önkormányzatok működési egyenlegei között kialakult szakadékot áthidalni, addig 10 évvel később ez már látványosan jobban sikerült. Az adósságkonszolidációt követő időszakban a támogatások figyelembevételével készített modell találati aránya több, mint 8 százalékponttal csökkent, a pszeudó $R$-négyzet értéke pedig közel felére esett vissza.

A 4. és 5. ábrán ${ }^{7}$ egy-egy pontdiagram segítségével is jól szemléltethető, hogy korábban

7. táblázat

\section{LOGISZTIKUS REGRESSZIÓS EREDMÉNYEK MIND A KÉT IDŐSZAKRA VONATKOZÓAN. ÁLLAMI TÁMOGATÁSOKKAL, ILLETVE TÁMOGATÁSOK NÉLKÜL EGYARÁNT}

\begin{tabular}{l|c|c|c|c|}
\hline \multirow{2}{*}{ Modell jósága } & \multicolumn{2}{c|}{ 2005-2008 } & \multicolumn{2}{c|}{ 2015-2018 } \\
\cline { 2 - 5 } & $\begin{array}{c}\text { Támogatás } \\
\text { nélkül }\end{array}$ & $\begin{array}{c}\text { Állami } \\
\text { támogatással }\end{array}$ & $\begin{array}{c}\text { Támogatás } \\
\text { nélk̈̈l }\end{array}$ & $\begin{array}{c}\text { Állami } \\
\text { támogatással }\end{array}$ \\
\hline Nagelkerke $R$-négyzet & 0,46 & 0,43 & 0,33 & 0,17 \\
\hline Találati arány (\%) & 77,4 & 79,6 & 73,0 & 64,8 \\
\hline ROC-görbe alatti terület & 0,85 & 0,85 & 0,81 & 0,72 \\
\hline
\end{tabular}

Megjegyzés: Az állami támogatások nélkül futatott modellek részletes eredményei a mellékletben találhatók.

Forrás: saját szerkesztés 


\section{SAJÁT MÚKÖDÉSI DEFICIT, ILLETVE A MÜKÖDÉSI TÁMOGATÁSOK KAPCSOLATA} (2005-2008, EZER FT/FÖ)

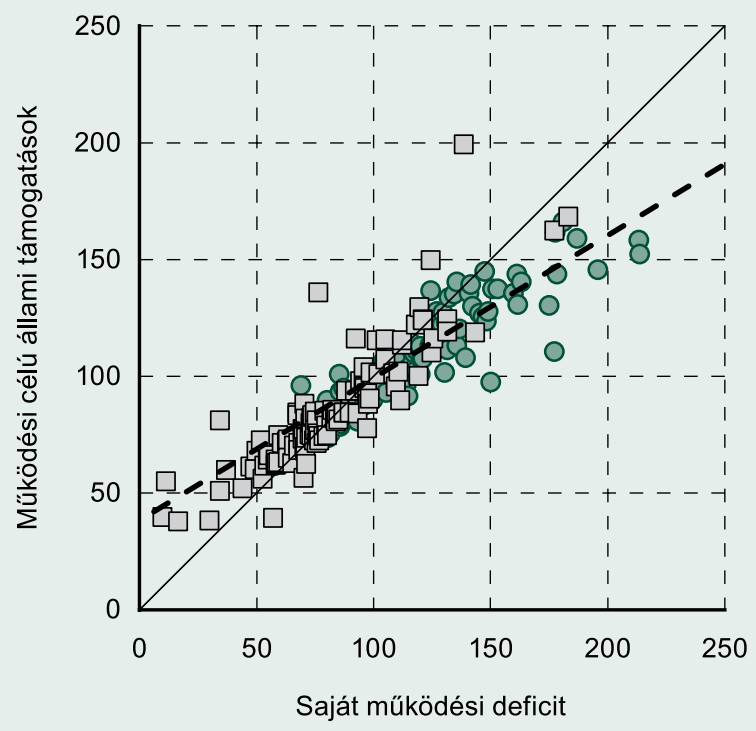

$$
\begin{gathered}
y=0,6099 x+38,281 \\
R^{2}=0,7934
\end{gathered}
$$

O Pénzügyi zavarokkal rendelkezö önkormányzatok

$\square$ Jól működő önkormányzatok

Forrás: saját szerkesztés

5. ábra

\section{SAJÁT MÜKÖDÉSI DEFICIT, ILLETVE A MÜKÖDÉSI TÁMOGATÁSOK KAPCSOLATA} (2015-2018, EZER FT/FÖ)

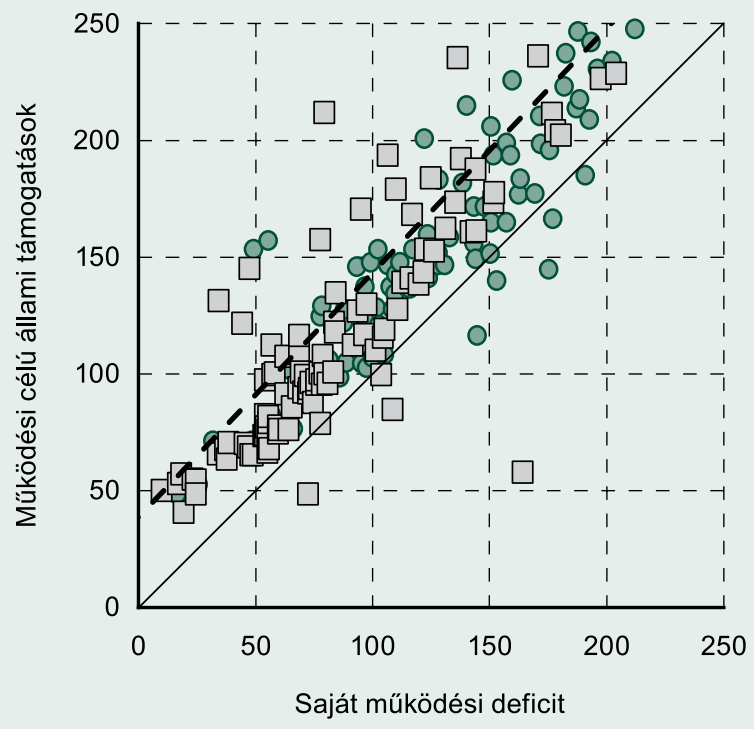

$$
\begin{gathered}
y=1,0459 x+38,858 \\
R^{2}=0,7423
\end{gathered}
$$

O Pénzügyi zavarokkal rendelkezö önkormányzatok

$\square$ Jól müködő önkormányzatok

Forrás: saját szerkesztés 
a támogatások mértéke nem egyenes arányban növekedett a működési deficit nagyságával. Amíg az egy före jutó hiány el nem érte a közel 100 ezer forintos értékét, addig a támogatások mértéke általában meghaladta a hiány nagyságát, míg ezt követőn a támogatások mértéke általában elmaradt a deficit mértékétől. Ezzel ellentétben, az adósságkonszolidációt követő időszakban a saját működési deficitekhez egyrészt jelentősebb működési támogatások társultak, másrészt jóval nagyobb terjedelemben szóródtak is ezek az összegek, a korábbi idöszakhoz képest.

\section{ÖSSZEGZÉS}

A válságot követő években az önkormányzati rendszer problémái is elötérbe kerültek. A nem megfelelően allokált feladatok és források, valamint a fejletlen kontrollrendszerek és a felelőtlen finanszírozási döntések következtében a települési önkormányzatok többsége pénzügyi problémákkal szembesült, melyek megoldása csak központi segítséggel volt megoldható. Az adósságok átvállalása, visszafizetésének támogatása mellett jelentős szerepet kapott a szabályozás minőségének fejlesztése is, mely a helyzet újbóli kialakulását hivatott megelőzni.

Első hipotézisünket, miszerint az adósságkonszolidációt megelőzően a pénzügyi zavarokkal küzdő és a jól működő önkormányzatok pénzügyi paraméterei szignifikánsan eltértek egymástól igazoltnak tekintjük. A logisztikus regresszió eredményei alapján az adósságkonszolidációban részesült önkormányzatok működési jövedelme jelentősen elmaradt az adósságkonszolidációban nem részesült önkormányzatokhoz képest, ami elsősorban az alacsonyabb saját bevételekkel magyarázható. Ezzel ellentétben, a hitelfelvételeknek köszönhetően a finanszírozási egyenlegeik pedig szignifikánsan magasabbak voltak. Az eredmények igazolják mások megfigyeléseit, miszerint a válság előtti években a kiegyensúlyozatlan forrás- és feladatallokáció révén nagymértékü különbségek alakultak ki az önkormányzatok között. A szabályozás nem ösztönözte a takarékos és hatékony gazdálkodást, ami kiegészült a hitelezők felelőtlenségével is.

A második hipotézisünk alapján az adósságkonszolidációt követően a két csoportnak közelednie kellett egymáshoz. Tekintettel arra, hogy a mintában szereplö önkormányzatokat a modell alapján kevésbé lehetett elkülöníteni ebben az időszakban, ezt a hipotézist is igazoltnak tekinthetjük. Vagyis a szabályozás megváltoztatása olyan szempontból eredményesnek tekinthető, hogy csökkentette a ,jól működo” és a „problémás” önkormányzatok közötti különbséget.

A harmadik hipotézisünket, mely szerint a teljes önkormányzati rendszer egészére pozitív hatást gyakorolt a szabályozás, szintén bizonyítottnak nyilváníthatjuk, ugyanis mind a „problémás” és mind a ,jól működő” önkormányzatok esetében javultak a pénzügyi paraméterek, ami elsősorban a bevételi oldal változásainak köszönhető.

Eredményeink hasonló következtetésekre engednek következtetni, mint a korábban megjelenő tanulmányok. Összességében, a pénzügyi egyenlegek esetében, melyeket a CLF-módszer is javasol az önkormányzatok gazdálkodásának értékelésére, jelentős változás, javulás történt. Ez elsősorban az általánosan magasabb és differenciáltabb állami támogatásoknak köszönhető, melyek feltételezhetően nagyobb összhangban állnak az egyes önkormányzatok működési sajátosságaival. A bevételi oldalon jelentős hatása volt az újbóli eladósodást megakadályozó intézkedéseknek, törvényeknek (Stabilitási törvény, Magyarország helyi önkormányzatairól szóló törvény), de emellett az integritási szemlélet megjelenésének, az ÁSZ ellenőrzéseinek, útmutatásainak és a belső kontroll fejlesztését célzó rendelkezéseknek. Viszont aggodalomra ad okot az a tény, hogy habár a bevételi olda- 
lon nem következett be jelentősebb változás, a kiadási oldalon számottevően növekedett a rés a korábban jól működő, illetve az adósságkonszolidációban részesült önkormányzatok között. A téma kapcsán még számos nyitott kérdés maradt, amely további kutatás tárgyát képezhetik. Érdekes eredményekre vezethetnének akár a belső kontrollal kapcsolatos minősítések modellekbe történő beépítései vagy különböző demográfiai változók bevonása, valamint más célváltozó alkalmazása, a zavarok más megközelítésekkel való vizsgálata.

MelléKLETeK

1. táblázat

\section{LOGISZTIKUS REGRESSZIÓS MODELL ÁLLAMI TÁMOGATÁSOK NÉLKÜL} A 2005-2008-AS IDÓSZAKBAN

\begin{tabular}{|l|r|r|r|r|r|c|}
\hline \multicolumn{1}{|c|}{ Változí } & B & S.E. & Wald & Sig. & Exp(B) & VIF \\
\hline Múködési egyenleg & $-3,149$ & 0,532 & 35,099 & 0,000 & 0,043 & 1,339 \\
\hline Felhalmozási egyenleg & $-0,088$ & 0,189 & 0,219 & 0,640 & 0,915 & 1,226 \\
\hline Finanszírozási egyenleg & 0,471 & 0,137 & 11,736 & 0,001 & 1,601 & 1,335 \\
\hline Tárgyévi egyenleg & $-0,239$ & 0,124 & 3,711 & 0,054 & 0,788 & 1,185 \\
\hline Konstans & $-15,315$ & 2,563 & 35,701 & 0,000 & 0,000 & \\
\hline
\end{tabular}

Forrás: saját szerkesztés

\begin{tabular}{|c|c|c|c|c|}
\hline \multirow{2}{*}{\multicolumn{2}{|c|}{ Klassziffkációs tábla }} & \multicolumn{2}{|c|}{ Modell alapján becsitlt } & \multirow{2}{*}{$\begin{array}{l}\text { Helyes besorolási } \\
\text { arány (\%) }\end{array}$} \\
\hline & & Jól mf́lködó & Pénzitgyi zavar & \\
\hline \multirow[t]{2}{*}{ Tényleges } & Jól múködő & 88 & 27 & 76,52 \\
\hline & Pénzügyi zavar & 25 & 90 & 78,26 \\
\hline Összesen & & & & 77,39 \\
\hline
\end{tabular}

Forrás: saját szerkesztés

2. táblázat

\section{LOGISZTIKUS REGRESSZIÓS MODELL ÁLLAMI TÁMOGATÁSOK NÉLKÜL A 2015-2018-AS IDÖSZAKBAN}

\begin{tabular}{l|r|r|r|r|r|c}
\hline \multicolumn{1}{|c|}{ Változó } & \multicolumn{1}{c|}{ B } & S.E. & Wald & Sig. & Exp(B) & VIF \\
\hline Múködési egyenleg & $-1,921$ & 0,330 & 33,865 & 0,000 & 0,146 & 1,013 \\
\hline Felhalmozási egyenleg & 0,260 & 0,183 & 2,032 & 0,154 & 1,297 & 1,001 \\
\hline Tárgyévi egyenleg & 0,084 & 0,084 & 0,989 & 0,320 & 1,087 & 1,013 \\
\hline Konstans & $-8,027$ & 1,544 & 27,031 & 0,000 & 0,000 & \\
\hline
\end{tabular}

Forrás: saját szerkesztés 
2. táblázat folytatása

\begin{tabular}{|c|c|c|c|c|}
\hline \multirow{2}{*}{\multicolumn{2}{|c|}{ Klassziffkációs tábla }} & \multicolumn{2}{|c|}{ Modell alapján becsitlt } & \multirow{2}{*}{$\begin{array}{c}\text { Helyes hesorolási } \\
\text { arány (\%) }\end{array}$} \\
\hline & & Jól mílködó & Pénzitgyi zavar & \\
\hline \multirow[t]{2}{*}{ Tényleges } & Jól múködő & 71 & 44 & 61,74 \\
\hline & Pénzügyi zavar & 18 & 97 & 84,35 \\
\hline Összesen & & & & 73,04 \\
\hline
\end{tabular}

Forrás: saját szerkesztés

1. ábra

A 2005-2008-AS IDŐSZAK LOGISZTIKUS REGRESSZIÓIHOZ TARTOZÓ ROC-GÖRBÉK

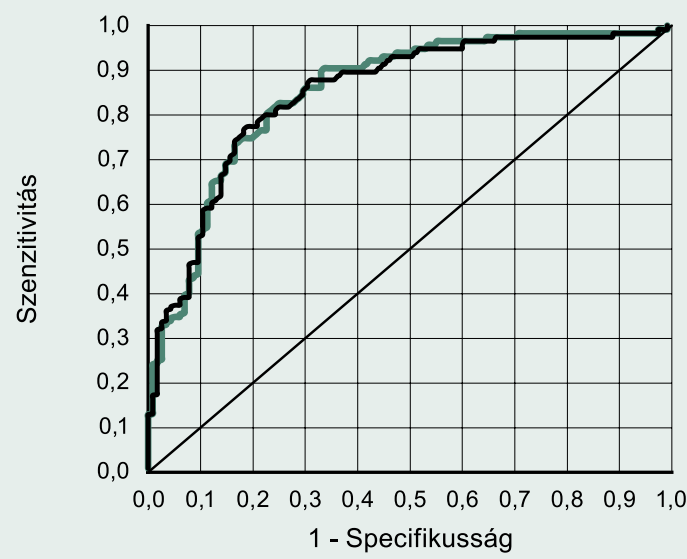

_Állami támogatások nélkül

—_Állami támogatásokkal

Forrás: saját szerkesztés

Il. ábra

\section{A 2015-2018-AS IDŐSZAK LOGISZTIKUS REGRESSZIÓIHOZ TARTOZÓ ROC-GÖRBÉK}

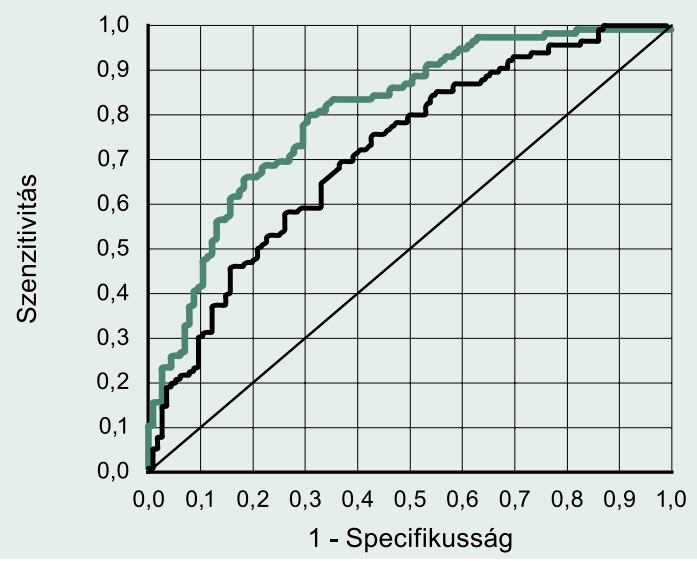

_Állami támogatások nélkül

—_Állami támogatásokkal 


\section{JEGYZETEK}

1 A kategorizálás alapjául szolgáló hírben a „adósságkonszolidációból kimaradó” nevet kapták az érintett települések. A könnyebb egyeztethetőség miatt a szerzők is átvették ezt az elnevezést. https://2015-2019.kormany.hu/hu/belugy miniszterium/onkormanyzati-allamtitkarsag/hi rek/9-5-milliardot-kapnak-az-adossagkonszoli daciobol-kimaradt-onkormanyzatok

2 https://2015-2019.kormany.hu/hu/belugyminiszterium/onkormanyzati-allamtitkarsag/hirek/9-5milliardot-kapnak-az-adossagkonszolidaciobolkimaradt-onkormanyzatok

3 A helyi önkormányzatok működési célú költségvetési támogatásairól szóló miniszteri döntés értelmében rendkívüli támogatásban az alábbi esetekben részesülhetnek az önkormányzatok: a) A települési önkormányzatok rendkívüli támogatást kivételes esetben, pályázat útján igényelhetnek működőképességük megőrzése vagy egyéb, a feladataik ellátását veszélyeztető helyzet elhárítása érdekében. Illetve $b$ ) Az előirányzat szolgál a tartósan fizetésképtelen helyzetbe került helyi önkormányzatok adósságrendezésére irányuló hitelfelvétel visszterhes kamattámogatására, és a pénzügyi gond- nok díjára; http://www.allamkincstar.gov.hu/hu/ nem-lakossagi-ugyfelek/helyi-onkormanyzatokmukodesi-celu-koltsegvetesi-tamogatasai

${ }^{4}$ Ellenkező esetben $1-p\left(x_{i}\right)=a z \quad i$ önkormányzat megfelelő működésének valószínűségét jelöli

5 Mivel az egyenlegek pozitív és negatív értékeket egyaránt felvehetnek abszolút értékekkel számoltunk. Illetve nagyrészük 0 közelében helyezkedik el, ezért minden értéket megnöveltünk 1-gyel, annak érdekében, hogy ezek ne váljanak kiugró értékké. A transzformálás alapegyenlete így, a következő formában írható fel, az eredeti értékek előjelének függvényében: $+/-\ln \left(\left|x_{i}\right|+1\right)$

6 A KSH Tájékoztatási Adatbázisa csak a 2017 és 2018-as évre vonatkozóan tartalmaz információkat a közfoglalkoztatottak számáról.

7 A számítások során figyelembe vett, azonban a szemléletesebb ábrázolás miatt az ábrán nem kerültek felmutatásra a támogatások nélkül is pozitív saját folyó egyenleggel, illetve az egy före vetített 250 ezer forintnál magasabb deficittel rendelkező önkormányzatok.

\section{IRODALOM}

Benedek M., Szenténé Tubak K., Béres D. (2014). Belső kontrollok a települési önkormányzatoknál. Pénzügyi Szemle, 59(3), 316-329. oldal

Bethlendi A. Lentner Cs. (2019). A magyar önkormányzati eladósodás és válságkezelés nemzetközi összehasonlításban. Közgazdasági Szemle, 64(10), 1013-1030. oldal

Bethlendi A., Lentner Cs., Nagy L. (2020). The Issue of Sustainability in a Highly Centrally Regulated Fiscal model of Local Governments: an
Empirical Study Issue of Sustainability. Accounting Research Journal, 33(6), https://doi.org/10.1108/ARJ-04-2020-0076

Carmelli, A., Cohen, A. (2001). The Financial Crises of Local Authorities of Israel: A ResourceBased Analysis. European Forum, 79(4), pp. 893913, https://doi.org/10.1111/1467-9299.00285

Dомокоs L. (2012). Kockázatok a mủködésben és a növekvő eladósodás a magyarországi önkormányzatoknál. Pénzügyi Szemle, 57(2), 165-173. oldal 
Domokos L., Pulay Gy. Z., Pető K., Pongrácz É. (2015). Az Állami Számvevőszék szerepe az államháztartás stabilitásának megteremtésében. Pénzügyi Szemle, 60(4), 427-443. oldal

Gál E. (2011). Kell-e szabályozni az önkormányzati hitelfelvételt? Pénzügyi Szemle, 56(1), 124-144. oldal

GYiRán Z. (2014). A Magyar önkormányzatok fizetésképtelenségi eljárásnak szabályozása, avagy “hungarikum”-e a Magyar adósságrendezési törvény. Új Magyar Közigazgatás, 7(1), 41-49. oldal

Halmosi P. (2013). A gazdasági válság hatása az OECD-országok önkormányzataira. Pénzügyi Szemle, 58(3), 296-309. oldal

Halmosi P. (2018). Detroit város 2013-as csődesetének tanulságai. Köz-Gazdaság, 13(2), 269-281. oldal

Hardle, W. K., Simar, L. (2015). Applied Multivariate Statistical Analysis. Springer, Berlin

Hegedűs Sz., Novoszáth P. (2018). Az önkormányzati rendszer átalakításának okai és az adósságkonszolidáció. Területi Statisztika, 58(6), 595-609. oldal

Hegedüs Sz., Lentner Cs., Molnár P. (2019). Múlt és jövő: az önkormányzati (vagyon) gazdálkodás új útjai az adósságkonszolidációt követően. Pénzügyi Szemle, 64(1), 49-69. oldal

Jones, S., Walker, R. G. (2007). Explanators ofLocal Government Distress. Abacus, 43(3), pp. 396-418, https://doi.org/10.1111/j.1467-6281.2007.00238.x

Kloha, P., Weissert, C. S., Kleine, R. (2005). Developing and Testing a Composite Model to Predict Local Fiscal Distress. Public Administration Review, 65(3), pp. 313-323, https://doi.org/10.1111/j.1540-6210.2005.00456.x
Lentner Cs. (2014). A magyar önkormányzatok adósságkonszolidációja. Pénzügyi Szemle, 59(3), 330-344. oldal

Lentner Cs. (2019). Önkormányzati pénz-és vagyongazdálkodás. Dialóg Campus, Budapest

Lentner Cs., Hegedűs Sz. (2019). Local SelfGovernments in Hungary: Recent Changes Through Central European Lenses. Central European Public Administration Review, 17(2), pp. 51-72

Nachar, N. (2008). The Mann-Whitney U: A Test for Assessing Whether Two Independent Samples Come from the Same Distribution. Tutorials in Quantitative Methods for Psychology, 4(1), pp. 13-20

Sepsey T. (2011). Belső ellenőrzés az önkormányzatoknál. Pénzügyi Szemle, 56(4), 401-418. oldal

Skidmore, M., Scorsone, E. (2011). Causes and Consequences of Fiscal Stress in Michigan Cities. Regional Science and Urban Economics, 41(4), pp. 360-371,

https://doi.org/10.1016/j.regsciurbeco.2011.02.007

Trussel, J. M., Patrick, P. A. (2013). The Symptoms and Consequences of Fiscal Distress in Municipalities: An Ivestigation of Reduction in Public Services. Accounting and Public Interest, 13(1), pp. 151-171, https://doi.org/10.2308/apin-10373

Smith, T. J., Mckenna, C. M. (2013). A Comparison of Logistic Regression Pseudo $\mathrm{R}^{2}$ Indices. Multiple Linear Regression Viewpoint, 39(2), pp. 17-26

VASVÁRI T. (2013). Az önkormányzatok 2011. évi gazdálkodása adósságszolgálatuk kiszorító hatásának tükrében. Pénzügyi Szemle, 58(4), 310-335. oldal 
VígVÁRI A. (2009). Atipikus önkormányzati eladósodás Magyarországon. Közgazdasági Szemle, 61(7-8), 709-730. oldal
VígVÁri A. (2010). Megtelt-e a konfliktuskonténer? Pénzügyi Szemle, 55(3), 465-487. oldal 